\title{
Self-Consistent Thermodynamic Parameters of Diopside at High Temperatures and High Pressures: Implications for the Adiabatic Geotherm of an Eclogitic Upper Mantle
}

\author{
Chang Su ${ }^{1,2,3}$, Dawei Fan ${ }^{2}$, Jiyi Jiang ${ }^{1,3}$, Zhenjun Sun ${ }^{1,3}$, Yonggang Liu ${ }^{2, *}$, Wei Song ${ }^{2}$, Yongge Wan ${ }^{1,3}$, \\ Guang Yang ${ }^{4}$ and Wuxueying Qiu ${ }^{1}$ \\ 1 School of Earth Sciences, Institute of Disaster Prevention, Sanhe 065201, China; suchang@cidp.edu.cn (C.S.); \\ jiangjiyi@cidp.edu.cn (J.J.); sunzhenjun@cidp.edu.cn (Z.S.); wanyg217217@vip.sina.com (Y.W.); \\ qiuwuxueying@outlook.com (W.Q.) \\ 2 Key Laboratory of High Temperature and High Pressure Study of the Earth's Interior, Institute of \\ Geochemistry, Chinese Academy of Sciences, Guiyang 550081, China; fandawei@vip.gyig.ac.cn (D.F.); \\ songwei@vip.gyig.ac.cn (W.S.) \\ 3 Hebei Key Laboratory of Earthquake Dynamics, Sanhe 065201, China \\ 4 School of Information Engineering, Institute of Disaster Prevention, Sanhe 065201, China; \\ yangguang@cidp.edu.cn \\ * Correspondence: liuyonggang@vip.gyig.ac.cn
}

check for updates

Citation: Su, C.; Fan, D.; Jiang, J.; Sun, Z.; Liu, Y.; Song, W.; Wan, Y.; Yang, G.; Qiu, W. Self-Consistent Thermodynamic Parameters of Diopside at High Temperatures and High Pressures: Implications for the Adiabatic Geotherm of an Eclogitic Upper Mantle. Minerals 2021, 11, 1322. https://doi.org/10.3390/ $\min 11121322$

Academic Editors: Lidong Dai, Haiying $\mathrm{Hu}$, Jianjun Jiang and Leonid Dubrovinsky

Received: 22 October 2021

Accepted: 22 November 2021

Published: 26 November 2021

Publisher's Note: MDPI stays neutral with regard to jurisdictional claims in published maps and institutional affiliations.

Copyright: (c) 2021 by the authors. Licensee MDPI, Basel, Switzerland. This article is an open access article distributed under the terms and conditions of the Creative Commons Attribution (CC BY) license (https:// creativecommons.org/licenses/by/ $4.0 /)$.

\begin{abstract}
Using an iterative numerical approach, we have obtained the self-consistent thermal expansion, heat capacity, and Grüneisen parameters of diopside $\left(\mathrm{MgCaSi}_{2} \mathrm{O}_{6}\right)$ over wide pressure and temperature ranges based on experimental data from the literature. Our results agree well with the published experimental and theoretical data. The determined thermodynamic parameters exhibit nonlinear dependences with increasing pressure. Compared with other minerals in the upper mantle, we found that the adiabatic temperature gradient obtained using the thermodynamic data of diopside is larger than that of garnet while lower than that of olivine, when ignoring the Fe incorporation. Combining our results with thermodynamic parameters of garnet obtained in previous studies, we have estimated the adiabatic temperature gradient and geotherm of an eclogitic upper mantle in a depth range of $200-450 \mathrm{~km}$. The results show that the estimated adiabatic temperature gradient of the eclogite model is $\sim 16 \%$ and $\sim 3 \%$ lower than that of the pyrolite model at a depth of $200 \mathrm{~km}$ and $410 \mathrm{~km}$, respectively. However, the high mantle potential temperature of the eclogite model leads to a similar temperature as the pyrolite model in a depth range of $200-410 \mathrm{~km}$.
\end{abstract}

Keywords: diopside; thermodynamic properties; eclogite model; adiabatic temperature gradient; adiabatic geotherm

\section{Introduction}

Temperature is one of the fundamental quantities for determining the physical and chemical properties of the Earth's interior. At present, however, it is impossible to measure the temperature of the deep Earth directly. Since the seismic discontinuities in the mantle are usually related to mineral phase transitions [1], the temperatures at the seismic discontinuities (i.e., the $410 \mathrm{~km}, 520 \mathrm{~km}, 660 \mathrm{~km}$ discontinuities and the mantle-core boundary) can be determined by comparing the depth of the seismic velocity discontinuities with the phase transition pressures of mantle minerals [2]. In addition, since the radiative transfer of heat is regarded to be negligible in the mantle, the temperature gradient of the mantle is expected to be nearly adiabatic [3]. As a consequence, the adiabatic temperature gradient $\left((\partial T / \partial z)_{S}\right)$ between two seismic discontinuities can be estimated using thermodynamic parameters at high temperatures and high pressures $(P-T s)$ via Equation $(1)[4,5]$ :

$$
\left(\frac{\partial T}{\partial z}\right)_{S}=\frac{\alpha g T}{C_{P}}=\left(\frac{\gamma T}{K_{S}}\right) \frac{g}{V}
$$


where $T$ and $z$ refer to the temperature and depth, respectively; $g$ refers to the gravitational acceleration; $K_{S}$ refers to the adiabatic bulk modulus; $V$ refers to the specific volume; and $\alpha, C_{P}$, and $\gamma$ refer to the thermal expansion, isobaric heat capacity, and Grüneisen parameters, respectively.

Based on thermodynamic principles and a model of the Earth [6], Stacey provided us with important insights into the thermal state of the Earth's interior [7]. Then, considering the temperatures at the seismic discontinuities, several authors also derived the thermodynamic parameters of the deep Earth with increasing depth using various thermal equations of state (EoS) [8-10]. In these studies, different seismic models and empirical equations or coefficients used in the estimations would cause significant discrepancies in the derived geotherms, consequently influencing the investigations into the physical and chemical properties of the mantle.

By comparing the elastic properties of major mantle minerals at $P-T$ s to global seismic models, the pyrolite and eclogite mantle models were proposed, which are particularly important to our understanding of deep-Earth mineral composition [1]. The pyrolite model is mainly composed of $\sim 60 \%$ olivine, $\sim 15 \%$ garnet, $\sim 15 \%$ clinopyroxene and $\sim 10 \%$ orthopyroxene at a depth of $\sim 200 \mathrm{~km}$, representing the bulk mantle mineral assemblages [11]. The eclogite model mainly consists of $\sim 30 \%$ garnet and $\sim 70 \%$ clinopyroxene at a depth of $200 \mathrm{~km}$, which refers to the bulk mineral assemblage of the subducted oceanic crust [12]. A decade ago, based on the thermal equations of states (EoS) of forsterite $\left(\mathrm{Mg}_{2} \mathrm{SiO}_{4}\right)$ and its high-pressure phase minerals [13-17], Katsura et al. [18] presented the adiabatic temperature gradient and geotherm of a pyrolitic mantle by using Equation (1). This work presented the idea that the adiabatic geotherm can be estimated using the thermodynamic properties of mantle minerals and specifically implied that the calculated adiabatic geotherm may be associated with the abundance of the minerals in the mantle. Recently, Su et al. modified a numerical iterative procedure and obtained the self-consistent thermodynamic properties of Fe-bearing olivine and garnet end-members at the $P-T$ range of the upper mantle [19-21] and presented the adiabatic temperature gradients by using Equation (1). The results indicated that not only different minerals but also chemical composition variations in the same groups of minerals might affect the estimated adiabatic temperature gradient. Thus, accurate thermodynamic parameters of mantle minerals at simultaneous $P-T$ s are urgently required to provide a better understanding of the relationship between the geotherm and the mineral composition.

Clinopyroxene is one of the main constituents of the upper mantle and the lower crust, and diopside $\left(\mathrm{CaMgSi}_{2} \mathrm{O}_{6}\right)$ with a space group of $\mathrm{C} 2 / \mathrm{c}$ is a vital calcium end-member of Ca-rich clinopyroxene [22]. Compared to the plentiful data on its elastic properties [23,24], thermodynamic data on diopside, especially under high-pressure conditions, are still lacking. Theoretically, the high-temperature and high-pressure thermal expansion of diopside can be derived from the volume at $P-T$ s measured through $X$-ray diffraction experiments $[23,25]$. However, the deduction of the pressure-volume-temperature $\left(P_{-}\right.$ $V-T$ ) relation requires empirical EoSs such as the third order Birch-Murnaghan EoS [26] or the Mie-Grüneisen-Debye EoS [27]. To date, the thermal expansion of diopside has only been published for ambient pressure conditions [28,29]. Meanwhile, since the heat capacity of diopside has only been measured at ambient pressure conditions [30-32], the available Grüneisen parameter data of diopside are consequently limited at ambient pressure conditions as well [33]. Moreover, the elastic and thermodynamic parameters of diopside have tended to be obtained individually via different methods. Still, it has been demonstrated that great care must be taken to preserve thermodynamic self-consistency in describing the temperature and pressure dependence of a material simultaneously [34,35].

This study reports the unit-cell volume, elastic moduli, thermal expansion, heat capacity, and Grüneisen parameters of diopside at high temperatures and high pressures, using an iterative numerical approach. To investigate the effect of mineral composition on the adiabatic temperature gradient, we present adiabatic temperature gradients calculated using thermodynamic data on olivine, garnet, and diopside. Finally, we apply the obtained ther- 
modynamic data on diopside to estimate the adiabatic temperature gradient and geotherm of an eclogitic upper mantle in a depth range of $200-450 \mathrm{~km}$, based on the assemblage of eclogitic mineral compositions, and compare our predictions with previous studies.

\section{Methods}

\subsection{Theory}

The approach used in this study has been described in published papers [19-21]; the fundamental equations are shown below. Note that the uncertainties of the derived parameters are estimated from the experimental measuring error propagations using a Taylor series expansion [20].

The thermal expansion at constant pressure is related to volume $(V)$ as $\alpha=(1 / V) \times$ $(\partial V / \partial T)_{P}$; the integration of this expression yields [36]

$$
V(T)=V_{T 0} \exp \left[\int_{T_{0}}^{T} \alpha(T) d T\right]
$$

where $V_{T 0}$ is the volume at a reference temperature $T_{0}$. The isothermal derivative of $V$ with respect to pressure can be written as

$$
\left(\frac{\partial V}{\partial P}\right)_{T}=-V^{2}\left(\frac{1}{v_{B}^{2}}+\frac{T \alpha^{2}}{C_{P}}\right)
$$

where $v_{B}$ refers to the bulk velocity, which is related to the P-wave velocity $\left(v_{P}\right)$ and Swave velocity $\left(v_{S}\right)$ as

$$
v_{B}=\left(v_{p}^{2}-\frac{4}{3} v_{s}^{2}\right)^{\frac{1}{2}}
$$

Moreover, the isothermal derivative of the heat capacity with respect to pressure can be evaluated by

$$
\left(\frac{\partial C_{P}}{\partial P}\right)_{T}=-V T\left[\alpha^{2}+\left(\frac{\partial \alpha}{\partial T}\right)_{P}\right]
$$

To start the calculation, first, we use the experimental volume data at high temperatures to obtain $\alpha\left(P_{0}, T\right)$ at ambient pressure by Equation (2). With $\alpha\left(P_{0}, T\right)$ and the relationship between $C_{P}$ and temperature at ambient pressure $C_{P}\left(P_{0}, T\right)$, the approximate $V$ at an arbitrary reference pressure can be estimated using Equation (3). Then, the resulting $V$ is used to update the value of $\alpha$ and $C_{P}$ at the same pressure as in Equations (2) and (5), respectively. Hence, iterations of this loop lead to converged values of $V, \alpha$, and $C_{P}$ as a function of temperature and pressure based on experimental elastic wave velocity. Furthermore, the self-consistent elastic parameters, including the adiabatic bulk modulus $\left(K_{S}\right)$, isothermal bulk modulus $\left(K_{T}\right)$, and shear modulus $(G)$, as well as the Grüneisen parameter $(\gamma)$, can be consequently derived (Equations (6)-(9)).

$$
\begin{gathered}
K_{S}=\frac{1}{V}\left(v_{p}^{2}-\frac{4}{3} v_{S}^{2}\right) \\
K_{T}=\frac{K_{S}}{1+\alpha \gamma T} \\
G=\frac{1}{V} v_{S}^{2} \\
\gamma=\frac{\alpha K_{S} V}{C_{P}}
\end{gathered}
$$




\subsection{Thermoelastic Data}

2.2.1. Elastic Wave Velocity under High-Temperature and High-Pressure Conditions

The elastic wave velocities of diopside have been obtained using Brillouin spectroscopy [37], ultrasonic interferometry [23], and first-principle calculations [24] under high-pressure conditions. The experimental data presented by Li and Neuville [23] indicated that $v_{P}$ and $v_{S}$ of diopside increase linearly with pressure and temperature within their measured $P-T$ range. Meanwhile, the results by Sang and Bass [37] and Zou et al. [24] suggested that both $v_{P}$ and $v_{S}$ show noticeable nonlinear dependence on pressure over $\sim 8 \mathrm{GPa}$. Hence, we use the data from Li and Neuville [23] and fit it with a two-dimensional equation:

$$
v=m_{0}+m_{1} \times(T-300)+m_{2} \times P+m_{3} \times P^{2}
$$

The fitting coefficients are listed in Table 1 , with $P$ in GPa, $T$ in $\mathrm{K}$, and $v_{P}$ and $v_{S}$ in $\mathrm{m} / \mathrm{s}$. The adjusted $R^{2}$ values are 0.979 and 0.953 for $v_{P}$ and $v_{S}$, respectively. The calculated elastic wave velocities for Equation (10) agree well with the available data [24,37]. The largest differences are less than $0.5 \%$ and $1.2 \%$ for $v_{P}$ and $v_{S}$, respectively, within our calculated $P-T$ range.

Table 1. Fitting coefficients for Equation (10).

\begin{tabular}{ccccc}
\hline & $m_{\mathbf{0}}$ & $m_{\mathbf{1}}$ & $m_{\mathbf{2}}$ & $\boldsymbol{m}_{\mathbf{3}}$ \\
\hline$v_{\boldsymbol{P}}$ & $8061.78( \pm 13.41)$ & $-0.402( \pm 0.019)$ & $101.21( \pm 4.42)$ & $-1.771( \pm 0.317)$ \\
$v_{S}$ & $4712.23( \pm 13.78)$ & $-0.329( \pm 0.019)$ & $33.60( \pm 4.55)$ & $-0.388( \pm 0.325)$ \\
\hline
\end{tabular}

\subsubsection{Unit-Cell Volume under High-Temperature and Ambient Pressure Conditions}

The ambient pressure unit-cell volumes of diopside were measured using X-ray diffraction at high temperatures $[28,29,38,39]$. In this study, we fitted the experimental volume data from Pandolfo et al. [28] to Equation (2) with the program EosFit7 GUI [40], thereby obtaining the thermal expansion as a function of temperature using the formula suggested by Fei [41]:

$$
\alpha(T)=2.8485(12) \times 10^{-5}+4.473(11) \times 10^{-9} T-0.2251(12) T^{-2}
$$

Here, we take $T_{0}=303 \mathrm{~K}$ and $V_{T 0}=428.70 \AA^{3}$, which are the values suggested by Pandolfo et al. [28]. The volumes calculated using Equations (2) and (11) show good agreement with the previous experimental results $[28,29,38,39]$, with the largest difference being less than $0.3 \%$.

\subsubsection{Heat Capacity under High-Temperature and Ambient Pressure Conditions}

The heat capacity of diopside at high temperatures below $1000 \mathrm{~K}$ has been determined by Stebbins et al. [32] and Krupka et al. [30] by using calorimetry. Then, Richet and Fiquet [31] extended the measuring temperature to $1600 \mathrm{~K}$, and the experimental data were fitted to different forms. Here, we use Equation (12), which was suggested by Richet and Fiquet [31] to be the best for describing their data:

$$
C_{P}=-186.908+57.729 \ln (T)+5.5483 \times 10^{4} T^{-1}-2.2557 \times 10^{7} T^{-2}+2.4436 \times 10^{9} T^{-3}
$$

where $C_{P}$ is in $\mathrm{J} / \mathrm{mol} \mathrm{K}$ and $T$ is in $\mathrm{K}$. The quality of the fit is excellent, with an adjusted $\mathrm{R}^{2}$ value of 0.993 and the largest error being $0.12 \%$.

\section{Results}

\subsection{Unit-Cell Volumes at High Temperatures and High Pressures}

Figure 1 presents comparisons between our calculated unit-cell volume of diopside (Supplementary Materials) and previously published results. At $300 \mathrm{~K}$, our data shows good agreement with the results measured using X-ray diffraction [42,43]. The excellent 
consistency with available experimental results also holds at high temperatures up to $1073 \mathrm{~K}[23,25]$, with the largest differences being less than $\sim 0.3 \%$. Though our unit-cell volume is slightly lower than the first-principle calculation result under high-temperature conditions [24], the uncertainty is within $1.2 \%$.

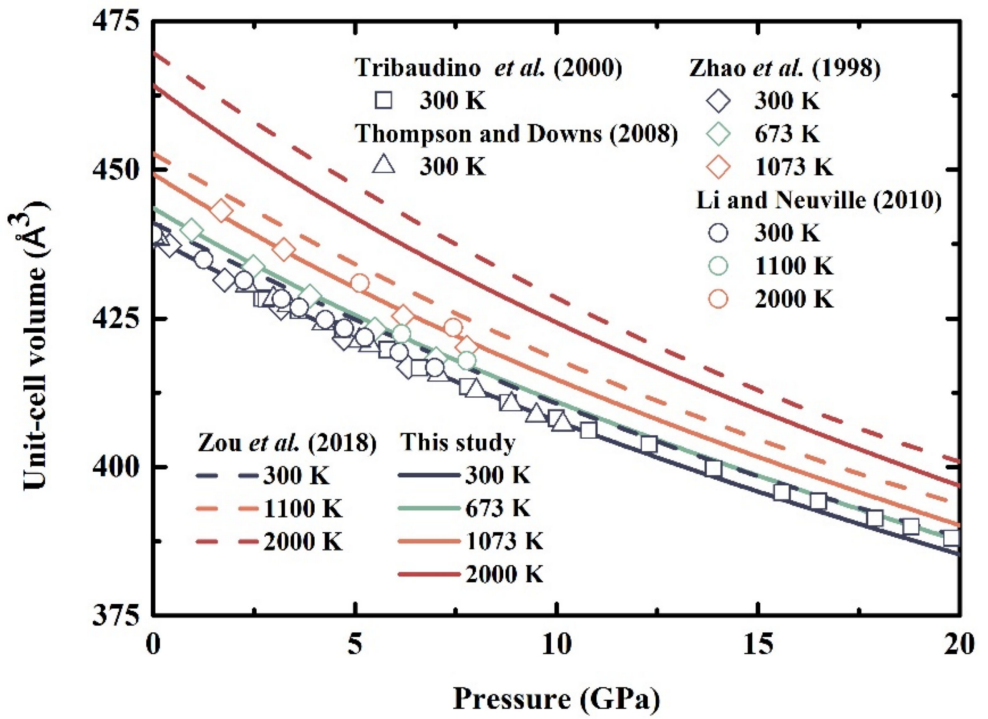

Figure 1. Unit-cell volume of diopside as a function of pressure at various temperatures. Solid lines refer to our calculated results, and dashed lines refer to the first-principle calculation results from Zou et al. (2018) [24]. The squares and triangles represent the measurements at $300 \mathrm{~K}$ by Tribaudino et al. (2000) [43] and Thompson and Downs (2008) [42], respectively. The diamonds and circles correspond to the measurements at various temperatures by Zhao et al. (1998) [25] and Li and Neuville (2010) [23], respectively.

\subsection{Elastic Properties at High Temperatures and High Pressures}

With the combination of the determined unit-cell volume and previously published $v_{P}$ and $v_{S}$ values at $P-T$ s [23], the $K_{T}, K_{S}$, and $G$ of diopside can be calculated via Equations (6)-(8); the results are shown in Table 2 and Figures 2 and 3.

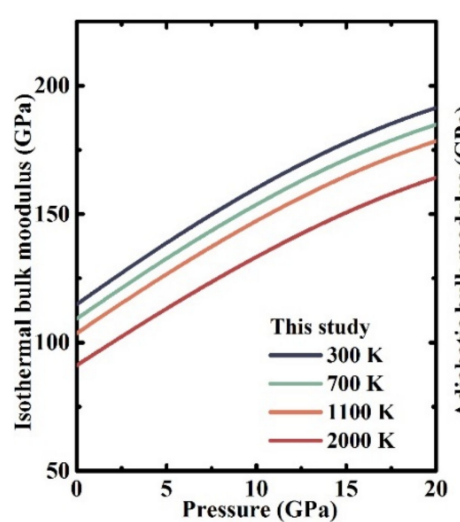

(a)

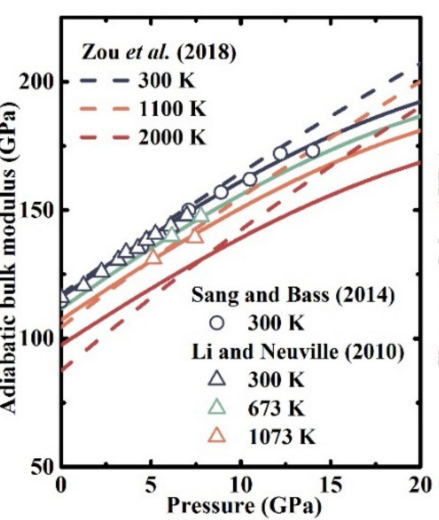

(b)

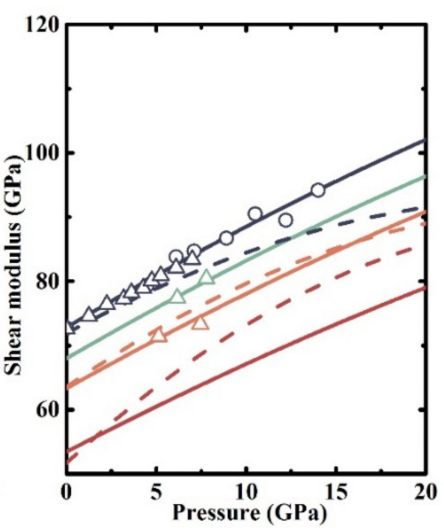

(c)

Figure 2. Elastic moduli of diopside as a function of pressure at various temperatures. Solid lines refer to our calculated results and dashed lines refer to the first-principle calculation results from Zou et al. (2018) [24]. The circles and triangles represent the results from Sang and Bass (2014) [37] and Li and Neuville (2010) [23], respectively. (a) Isothermal bulk modulus (b) Adiabatic bulk modulus (c) Shear modulus. 


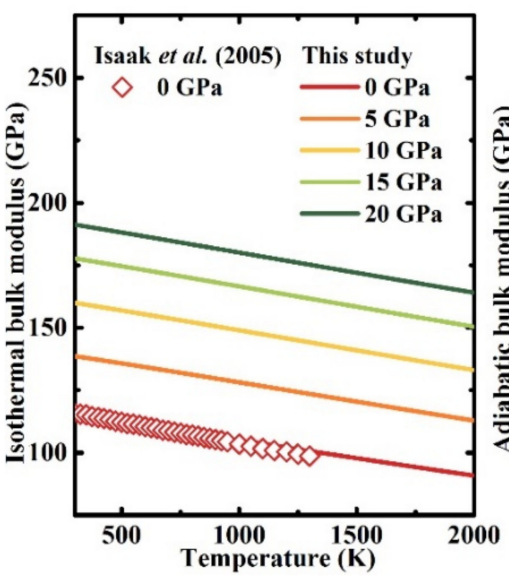

(a)

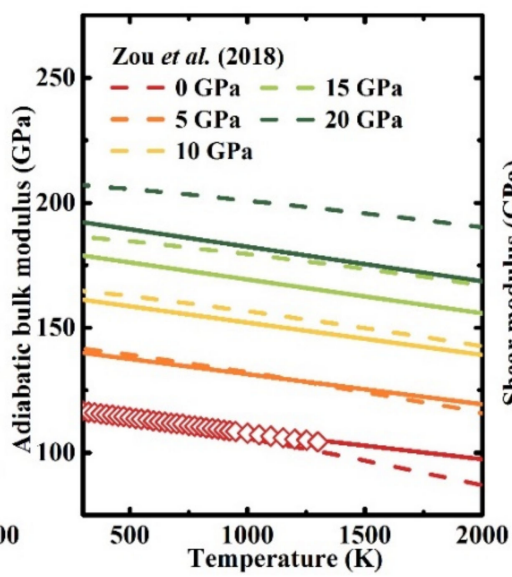

(b)

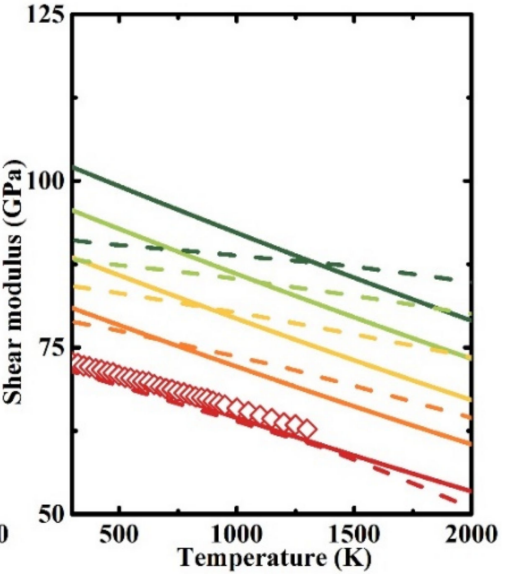

(c)

Figure 3. Elastic moduli of diopside as a function of temperature at various pressures. Solid lines refer to our calculated results and dashed lines refer to the first-principle calculation results from Zou et al. (2018) [24]. The diamonds correspond to the results from Isaak et al. (2006) [33]. (a) Isothermal bulk modulus (b) Adiabatic bulk modulus (c) Shear modulus.

As shown in Table 2, the $K_{T}, K_{S}$, and $G$ values under ambient conditions have been determined as $114.8 \mathrm{GPa}, 116 \mathrm{GPa}$, and $72.8 \mathrm{GPa}$, respectively, which generally agree with the experimental $[23,25,37,42-45]$ and theoretical [24,46] results. All three elastic moduli show a nonlinear relationship with pressure and a linear relationship with temperature. At room temperature, the first pressure derivatives of the elastic moduli have been determined as $\partial K_{T} / \partial P$ $=5.17, \partial K_{S} / \partial P=5.18$, and $\partial G / \partial P=1.67$, and the second pressure derivatives of elastic moduli have been determined as $\partial^{2} K_{T} / \partial P^{2}=-0.066 / G P a, \partial^{2} K_{S} / \partial P^{2}=-0.067 / G P a$, and $\partial^{2} G / \partial P^{2}$ $=-0.0106 / \mathrm{GPa}$. Also, the temperature derivatives of elastic moduli have been determined as $\partial K_{T} / \partial T=-0.0142 \mathrm{GPa} / \mathrm{K}, \partial K_{S} / \partial T=-0.011 \mathrm{GPa} / \mathrm{K}$, and $\partial G / \partial T=-0.0114 \mathrm{GPa} / \mathrm{K}$ under ambient pressure conditions; these values are consistent with previously presented results [23-25].

Table 2. Elastic moduli of diopside and their first and second derivatives with respect to pressure and temperature.

\begin{tabular}{|c|c|c|c|c|}
\hline $\begin{array}{l}\mathrm{K}_{T 0} \\
\mathrm{GPa}\end{array}$ & $\left(\partial K_{T} / \partial P\right)_{T}$ & $\begin{array}{c}\left(\partial^{2} K_{T} / \partial P^{2}\right)_{T} \\
/ G P a\end{array}$ & $\begin{array}{c}\left(\partial K_{T} / \partial T\right)_{P} \\
10^{-2} \mathrm{GPa} / \mathrm{K}\end{array}$ & References \\
\hline $114(4)$ & $4.5(1.8)$ & & & Levien and Prewitt (1981) [44] \\
\hline 109.1 & 4.84 & & -2.05 & Zhao et al. (1998) [25] \\
\hline $105.1(9)$ & $6.8(1)$ & & - & Tribaudino et al. (2000) [43] \\
\hline $118(1)$ & $3.8(2)$ & & & Thompson and Downs (2008) [42] \\
\hline 122 & 4.7 & & & Walker et al. (2008) [46] \\
\hline 116.4 & 4.62 & & -1.72 & Zou et al. (2018) [24] \\
\hline 114.8 & 5.17 & -0.066 & -1.42 & This study \\
\hline $\begin{array}{l}K_{S 0} \\
\mathrm{GPa}\end{array}$ & $\left(\partial K_{S} / \partial P\right)_{T}$ & $\begin{array}{c}\left(\partial^{2} K_{S} / \partial P^{2}\right)_{T} \\
/ G P a\end{array}$ & $\begin{array}{c}\left(\partial K_{S} / \partial T\right)_{P} \\
10^{-2} \mathrm{GPa} / \mathrm{K}\end{array}$ & References \\
\hline $116.4(7)$ & $4.9(1)$ & & $-1.2(1)$ & Li and Neuville (2010) [23] \\
\hline $114.6(7)$ & & & & Sang et al. (2011) [45] \\
\hline $114.6(7)$ & $4.8(2)$ & & & Sang and Bass (2014) [37] \\
\hline 117.5 & 5.0 & -0.026 & -1.5 & Zou et al. (2018) \\
\hline 116.0 & 5.18 & -0.067 & -1.10 & This study \\
\hline $\begin{array}{c}G_{0} \\
G P a\end{array}$ & $(\partial G / \partial P)_{T}$ & $\begin{array}{c}\left(\partial^{2} G / \partial P^{2}\right)_{T} \\
/ G P a\end{array}$ & $\begin{array}{c}(\partial G / \partial T)_{P} \\
10^{-2} \mathrm{GPa} / \mathrm{K}\end{array}$ & References \\
\hline $73.0(4)$ & $1.6(1)$ & & $-1.1(1)$ & Li and Neuville (2010) [23] \\
\hline $72.7(4)$ & & & & Sang et al. (2011) [45] \\
\hline $72.7(4)$ & $1.7(1)$ & & & Sang and Bass (2014) [37] \\
\hline 71.8 & 1.56 & -0.0302 & -0.871 & Zou et al. (2018) [24] \\
\hline 72.8 & 1.67 & -0.0106 & -1.14 & This study \\
\hline
\end{tabular}


The pressure and temperature dependences of these elastic moduli are shown in Figures 2 and 3, respectively. In Figure 2b,c, the calculated $K_{S}$ and $G$ values are in good agreement with the available experimental measurements under the relevant conditions $[23,37]$. Also, in Figure $2 b$, our ambient and high temperature $K_{S}$ values generally agree with the first-principle calculations performed by Zou et al. [24] for under 10 GPa. Then, the pressure derivative becomes smaller than that from Zou et al. [24], leading to a significant separation of $\sim 10 \%$ at $20 \mathrm{GPa}$. Then, in Figure $2 \mathrm{c}$, our calculated $G$ value is in good agreement with the result from Zou et al. [24] at $1100 \mathrm{~K}$. Compared to Zou et al. [24], our result is larger than that from Zou et al. [24] at $300 \mathrm{~K}$, and smaller than that from Zou et al. [24] at $2000 \mathrm{~K}$.

In Figure 3, at ambient pressure, our elastic moduli are generally consistent with the experimental study by Isaak et al. [33], which presented the ambient pressure elastic properties of chrome-diopside. The largest differences between our and Isaak's results are $2.1 \%, 0.6 \%$, and $2.8 \%$ for $K_{T}, K_{S}$, and $G$, respectively. In addition, our $K_{S}$ and $G$ values are generally consistent with the results from Zou et al. [24] below $10 \mathrm{GPa}$. Then, the separations get more significant along with the pressure due to the differences in the pressure derivatives of $K_{\mathrm{S}}$ and $G$.

\subsection{Thermodynamic Properties at High Temperatures and High Pressures}

Our calculated thermal expansion, heat capacity, and Grüneisen parameters of diopside are illustrated in Figures 4-6, respectively. Figure 4a shows the temperature dependence of the thermal expansion of diopside at several pressure conditions, as well as previous results for comparisons. At ambient pressure, the temperature derivative of our calculated thermal expansion $\partial \alpha / \partial T$ is $\sim 5.0 \times 10^{-4} / \mathrm{K}^{2}$ over $500 \mathrm{~K}$. This value is lower than that presented by Isaak et al. [33], which was obtained from the combination of previous studies $[38,39,47]$. Moreover, the difference in $\partial \alpha / \partial T$ causes a $17 \%$ deviation at $1300 \mathrm{~K}$. On the other hand, our result is in good agreement with the recent data obtained via an X-ray diffraction study by Hovis et al. [29], with the largest difference being $4.7 \%$ in the temperature range of $500-1500 \mathrm{~K}$.

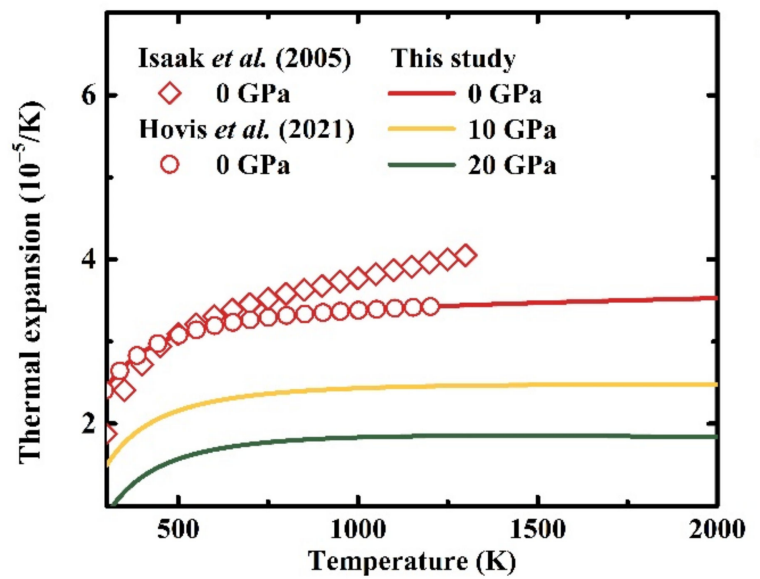

(a)

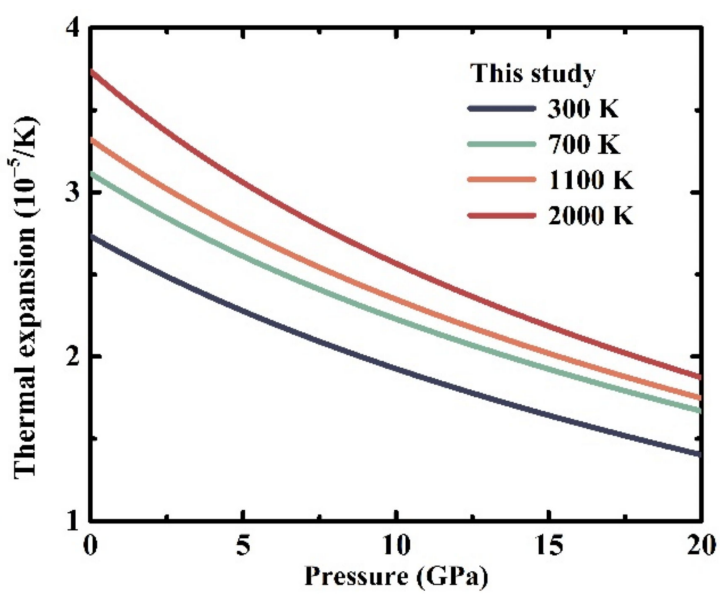

(b)

Figure 4. Temperature (a) and pressure (b) dependences of the thermal expansion of diopside. Solid lines refer to our calculated results. The diamonds and circles correspond to the results from Isaak et al. (2006) [33] and Hovis et al. (2021) [29], respectively. 


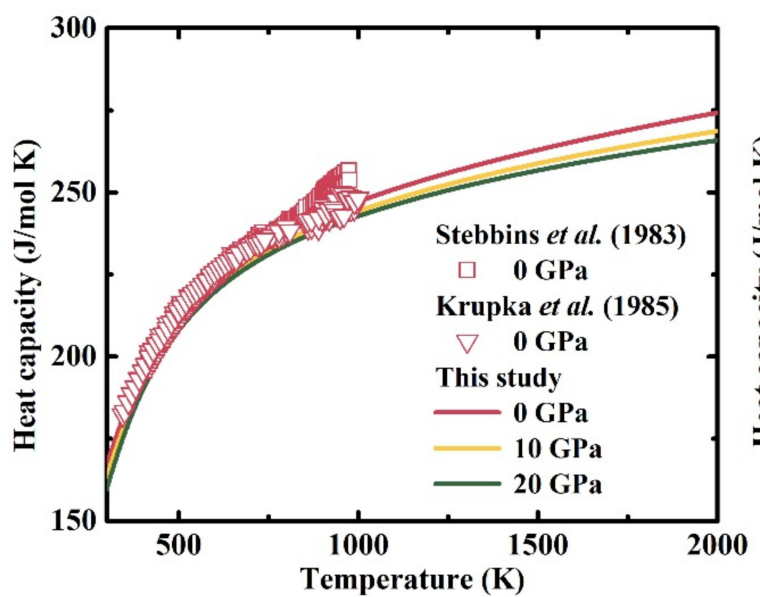

(a)

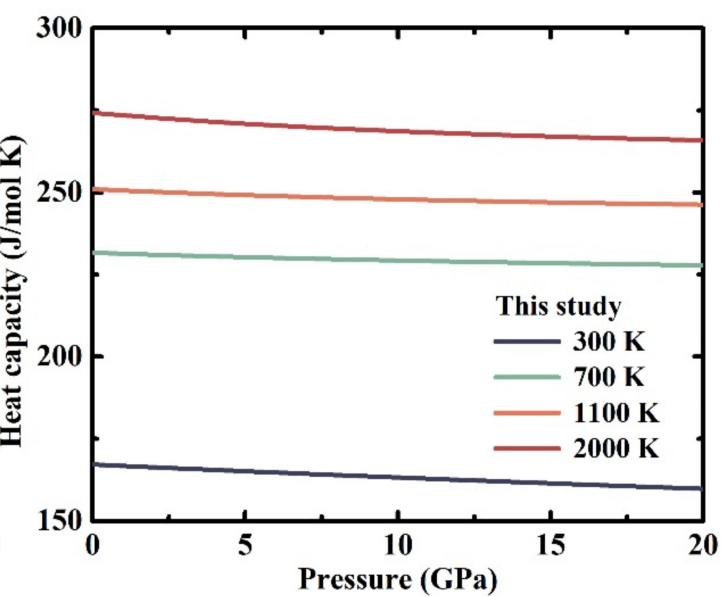

(b)

Figure 5. Temperature (a) and pressure (b) dependences of the heat capacity of diopside. Solid lines refer to our calculated results. The squares and triangles correspond to the results from Stebbins et al. (1983) [32] and Krupka et al. (1985) [30], respectively.

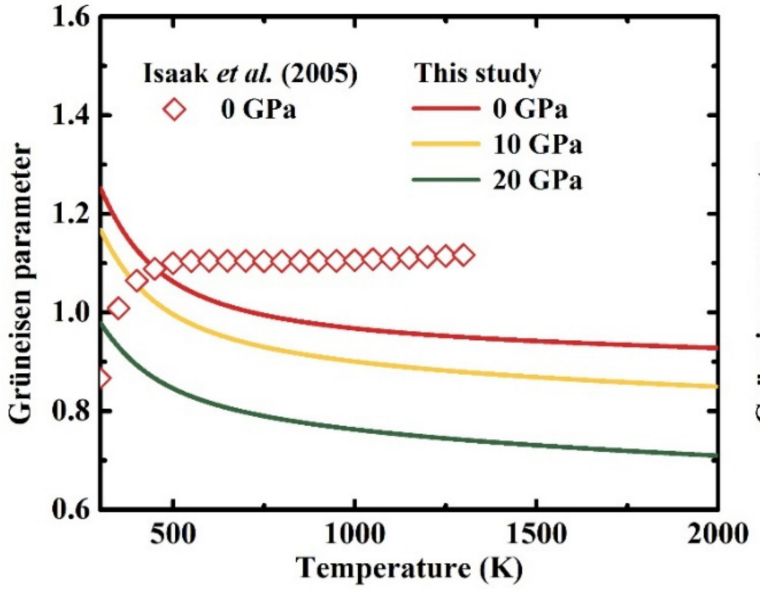

(a)

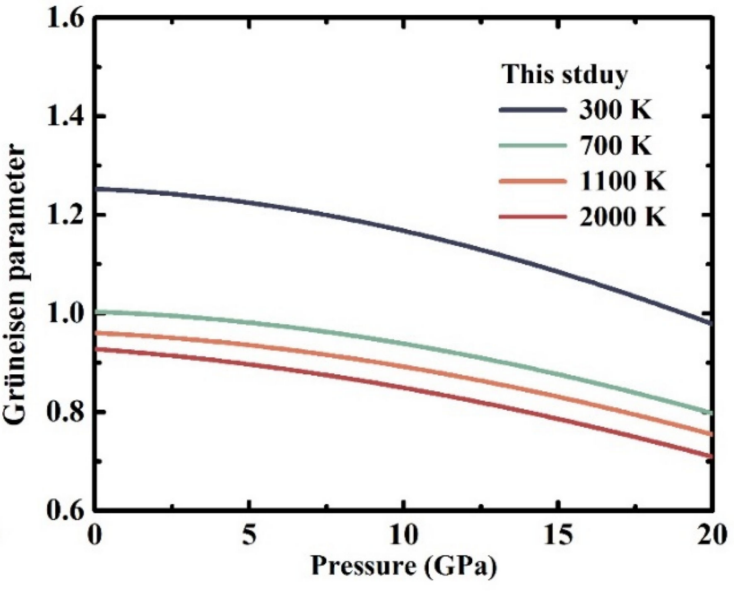

(b)

Figure 6. Temperature (a) and pressure (b) dependences of the Grüneisen parameter of diopside. Solid lines refer to our calculated results. The diamonds correspond to the results from Isaak et al. (2006) [33].

Currently, the published heat capacities of diopside are limited under ambient conditions. In Figure 5a, since the heat capacity of diopside for our calculation was taken from previous experimental studies [31], our obtained heat capacity is in good agreement with the experimental data presented by Krupka et al. [30], with a difference of 1.9\%, and generally agrees with the result presented by Stebbins et al. [32] below $\sim 850 \mathrm{~K}$, with a difference of $1.5 \%$.

The Grüneisen parameter is a valuable thermodynamic parameter in geophysics which can set limitations on the pressure and temperature dependence of the thermal properties of the mantle and core and constrain the adiabatic temperature gradient [48]. In Figure $6 \mathrm{a}$, our calculated Grüneisen parameter shows a rapid decrease to $\sim 500 \mathrm{~K}$ and then tends to nearly a constant, with a very small temperature derivative of $-5.0 \times 10^{-5} / \mathrm{K}$ at $2000 \mathrm{~K}$. The result is $15 \%$ lower than that from Isaak et al. [33] at $1300 \mathrm{~K}$, which is probably caused by the difference in the chemical composition of minerals. Also, the Grüneisen parameter proposed by Isaak et al. [33] demonstrated a rapid increase below $\sim 500 \mathrm{~K}$; in contrast, our determined data shows an opposite trend, exhibiting a similar pattern to garnet and olivine under ambient pressure conditions [20,49]. 
Additionally, to investigate the effects of pressure on the thermodynamic properties of diopside, the calculated thermal expansion, heat capacity, and Grüneisen parameters as a function of pressure at different temperatures are illustrated in Figures $4 b, 5 b$ and $6 b$, respectively. All $\alpha, C_{P}$, and $\gamma$ values for diopside show nonlinear pressure dependences. Hence, we fitted the thermodynamic parameters into the equation $N=N_{0}+\partial N / \partial P \times P+$ $\partial^{2} N / \partial P^{2} \times P^{2}$ at different temperatures; where $N$ refers to the thermodynamic properties; $N_{0}$ refers to $N$ ambient pressure; and $\partial N / \partial P$ and $\partial^{2} N / \partial P^{2}$ refer to the first and second pressure derivatives of $N$, respectively. The fitting coefficients are listed in Table 3 .

Table 3. The thermal expansion, heat capacity, and Grüneisen parameters of diopside and their first and second derivatives with respect to pressure.

\begin{tabular}{|c|c|c|c|}
\hline $\begin{array}{l}T \\
\mathrm{~K}\end{array}$ & $\begin{array}{c}\alpha_{0} \\
10^{-5} / \mathrm{K}\end{array}$ & $\begin{array}{c}\partial \alpha / \partial P \\
10^{-6} / \mathrm{K} \mathrm{GPa}\end{array}$ & $\begin{array}{c}\partial^{2} \alpha / \partial P^{2} \\
10^{-8} / \mathrm{KGPa}^{2}\end{array}$ \\
\hline 300 & 2.71 & -0.92 & 1.4 \\
\hline 700 & 3.09 & -1.02 & 1.6 \\
\hline 1100 & 3.29 & -1.13 & 1.8 \\
\hline 2000 & 3.70 & -1.37 & 2.4 \\
\hline$T$ & $C_{P 0}$ & $\partial C_{P} / \partial P$ & $\partial^{2} C_{P} / \partial P^{2}$ \\
\hline $\mathbf{K}$ & $\mathrm{J} / \mathrm{mol} \mathrm{K}$ & $\mathrm{J} / \mathrm{mol} \mathrm{K} \mathrm{GPa}$ & $10^{-3} \mathrm{~J} / \mathrm{mol} \mathrm{K} \mathrm{GPa}^{2}$ \\
\hline 300 & 167.15 & -0.417 & 2.3 \\
\hline 700 & 231.57 & -0.275 & 4.5 \\
\hline 1100 & 250.91 & -0.372 & 7.2 \\
\hline 2000 & 274.09 & -0.688 & 14.2 \\
\hline$T$ & & $\partial \gamma / \partial P$ & $\partial^{2} \gamma / \partial P^{2}$ \\
\hline K & $\gamma_{0}$ & $10^{-3} / \mathrm{GPa}$ & $10^{-4} / \mathrm{GPa}^{2}$ \\
\hline 300 & 1.254 & -3.4 & -5.2 \\
\hline 700 & 1.004 & -2.7 & -3.8 \\
\hline 1100 & 0.961 & -3.4 & -3.5 \\
\hline 2000 & 0.928 & -4.8 & -3.1 \\
\hline
\end{tabular}

In Table 3 , all $\alpha, C_{P}$, and $\gamma$ values show negative pressure dependences, and the effects of pressure on $\alpha$ and $C_{P}$ increase along with the temperature. At room temperature, the first pressure derivative of $\alpha$ is $\partial \alpha / \partial P=-0.92 \times 10^{-6} / \mathrm{K} \mathrm{GPa}$. This value is larger than that suggested by Zhao et al. [25] $\left(-1.52(2) \times 10^{-6} / \mathrm{K} \mathrm{GPa}\right)$, which was determined in the $\mathrm{P}-\mathrm{T}$ range of $8.2 \mathrm{GPa}$ and $1280 \mathrm{~K}$ with a linear fitting equation. Then, increasing the temperature to $2000 \mathrm{~K}, \partial \alpha / \partial P$ decreases to $\partial \alpha / \partial P=-1.37 \times 10^{-6} / \mathrm{K}$ GPa. Similarly, the pressure derivative of $C_{P}\left(\partial C_{P} / \partial P\right)$ decreases from $-0.417 \mathrm{~J} / \mathrm{mol} \mathrm{K} \mathrm{GPa} \mathrm{to}-0.688 \mathrm{~J} / \mathrm{mol}$ $\mathrm{K} \mathrm{GPa}$ in the temperature range of $300-2000 \mathrm{~K}$. In particular, the first pressure derivative of the Grüneisen parameter is $\partial \gamma / \partial P=-3.4 \times 10^{-3} / \mathrm{GPa}$ at room temperature. Then, the value increases with temperature to $-2.6 \times 10^{-3} / \mathrm{GPa}$ at $\sim 500 \mathrm{~K}$ because of the variations at the low-temperature range, and decreases with the temperature again to $-4.8 \times 10^{-3} / \mathrm{GPa}$ at $2000 \mathrm{~K}$.

\section{Discussion}

\subsection{Effect of Mineral Composition on the Adiabatic Temperature Gradient}

Based on the obtained thermodynamic data on diopside, we have estimated the adiabatic temperature gradient $\left((\partial T / \partial z)_{S}\right)$ by using Equation (1); the result is shown in Figure 7 . To investigate the effect of mineral composition on the adiabatic temperature gradient, the $(\partial T / \partial z)_{S}$ values obtained using thermodynamic data on Fe-bearing olivine $\left(\left[\mathrm{Fe}_{0.2} \mathrm{Mg}_{0.8}\right]_{2} \mathrm{SiO}_{4}\right)$, pyrope $\left(\mathrm{Mg}_{3} \mathrm{Al}_{2}\left[\mathrm{SiO}_{4}\right]_{3}\right)$, almandine $\left(\mathrm{Fe}_{3} \mathrm{Al}_{2}\left[\mathrm{SiO}_{4}\right]_{3}\right)$, and grossular $\left(\mathrm{Ca}_{3} \mathrm{Al}_{2}\left[\mathrm{SiO}_{4}\right]_{3}\right)$ are also illustrated in Figure 7 for comparison [19-21]. Note that the mantle potential temperature $\left(T_{P}\right)$, which refers to the temperature that it would have upon ascending adiabatically to the Earth's surface without undergoing partial melting [50], is 
employed as $T_{P}=1610 \mathrm{~K}$ [18]. Additionally, the pressure and gravitational acceleration variations with depth are from the study performed by Stacey and Davis [4].

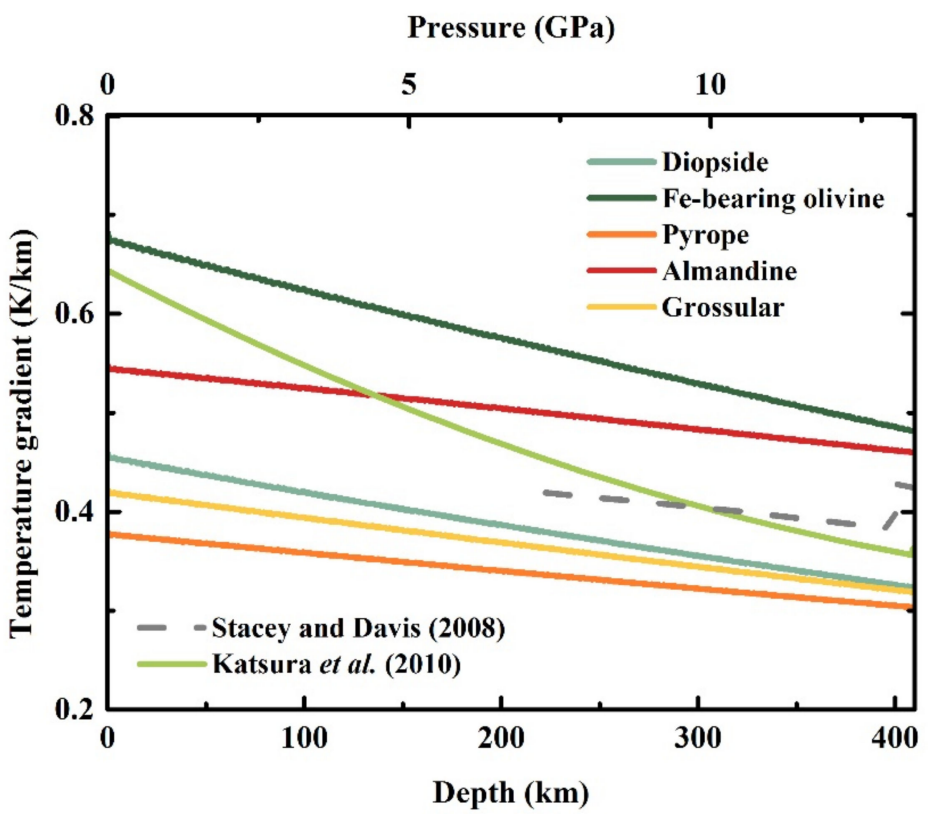

Figure 7. Adiabatic temperature gradients obtained using thermodynamic data on minerals $\left(T_{P}=1610 \mathrm{~K}\right)$.

The $(\partial T / \partial z)_{S}$ values obtained using thermodynamic data on diopside are $0.46 \mathrm{~K} / \mathrm{km}$, $0.39 \mathrm{~K} / \mathrm{km}$, and $0.32 \mathrm{~K} / \mathrm{km}$ at depths of $0 \mathrm{~km}, 200 \mathrm{~km}$, and $410 \mathrm{~km}$, respectively; the value is $\sim 14 \%$ lower than that obtained by Stacey and Davis [4] in the depth range of $220-410 \mathrm{~km}$. For the Fe-free minerals, at a depth of $200 \mathrm{~km}$, the $(\partial T / \partial z)_{S}$ value obtained using thermodynamic data on diopside is $14 \%$ and $5 \%$ higher than that of pyrope and grossular, respectively, whilst it is $17 \%$ lower than that of forsterite. Also, this value is $33 \%$ and $23 \%$ lower than that of the Fe-bearing olivine and Fe-bearing garnet (almandine), respectively. Moreover, a previous study suggested that the depth derivatives of $(\partial T / \partial z)_{S}$ of those minerals from the same group are similar [20]. In this study, the depth derivative of $(\partial T / \partial z)_{S}$ obtained from thermodynamic data on diopside is $-3.0 \times 10^{-4} \mathrm{~K} / \mathrm{km}^{2}$ in the depth range of $200-410 \mathrm{~km}$, which is smoother than that of olivine $\left(-5.0 \times 10^{-4} \mathrm{~K} / \mathrm{km}^{2}\right)$ and steeper than that of garnet $\left(-2.0 \times 10^{-4} \mathrm{~K} / \mathrm{km}^{2}\right)[20]$.

\subsection{Adiabatic Geotherm of the Eclogite Model}

It is widely accepted that the bulk mantle mineral assemblages can be represented by the pyrolite model [11,51]. The seismic discontinuities at depths of $410 \mathrm{~km}, 520 \mathrm{~km}$, and $660 \mathrm{~km}$ are associated with the phase transitions from $(\mathrm{Mg}, \mathrm{Fe})_{2} \mathrm{SiO}_{4}$ olivine ( $\alpha$-phase) to wadsleyite ( $\beta$-phase) and from wadsleyite to ringwoodite ( $\gamma$-phase) and the dissociation of ringwoodite into bridgmanite and periclase, respectively, for the pyrolite model $[52,53]$. Hence, the temperature at these seismic discontinuities can be estimated by comparing the depth of these seismic discontinuities with the transition pressures in the system $\mathrm{Mg}_{2} \mathrm{SiO}_{4}-\mathrm{Fe}_{2} \mathrm{SiO}_{4}[2,18]$. With the combination of the thermal equations of states of $(\mathrm{Mg}$, $\mathrm{Fe})_{2} \mathrm{SiO}_{4}$ olivine and its high-pressure phase minerals, as well as Equation (1), the adiabatic temperature gradient $(\partial T / \partial z)_{S}$ and adiabatic geotherm of a pyrolitic mantle was presented for $\sim 3000 \mathrm{~km}$ by Katsura et al. [18], which has been widely used in later investigations.

Meanwhile, the upper mantle under the subducted oceanic crust is generally considered eclogitic in composition [12,54]. The subducting slab has a layered structure: overlying crust of mid-ocean ridge basalt (MORB), followed by residual harzburgite and depleted pyrolite from top to bottom [55,56]. When the subducting slab is subducted into the mantle, the MORB transforms directly into eclogite, which mainly contains an assemblage of 
eclogitic garnet and clinopyroxene, and becomes denser than the harzburgite underlying it $[57,58]$. Then, the clinopyroxene starts to dissolve progressively into stishovite and garnet, which then completely forms majoritic garnet by a depth of $\sim 450 \mathrm{~km}$ [59-61]. Hence, the mineral composition of an eclogitic upper mantle is quite different from a pyrolitic upper mantle, which raises the question: Will the geotherm of the eclogite model also be different from the pyrolite model?

In order to estimate the adiabatic geotherm of an eclogitic upper mantle with Equation (1), it is necessary to determine the $T_{P}$ of the oceanic mantle first. Previous research on the generation of the oceanic upper mantle proposed the $T_{P}$ of mid-ocean ridges as $1533 \mathrm{~K}$ [62]; then, the temperature was suggested to be hotter $[63,64]$. Recently, with the consideration of water content of the peridotite in MORB, the $T_{P}$ of mid-ocean ridges was constrained to $1623-1683 \mathrm{~K}$ [65]. Also, the composition at the top of an eclogitic upper mantle $(200 \mathrm{~km})$ is $\sim 70 \%$ clinopyroxene, and $\sim 30 \%$ eclogitic garnet [66]. Therefore, with the high temperature and high pressure thermodynamic data on diopside and eclogitic garnet, the temperature at a depth of $200 \mathrm{~km}$ can be estimated as 1699-1762 K via Equation (13) [50]. It is worth noting that the eclogitic garnet is composed of approximately $40 \%$ pyrope, $30 \%$ almandine, and $30 \%$ grossular $[67,68]$.

$$
T_{P}=\operatorname{Texp}\left(-\frac{g \alpha z}{C_{P}}\right)
$$

Based on the variations of mineral volume fraction with depth presented by Irifune et al. [66], our calculated $(\partial T / \partial z)_{S}$ value of the eclogite model in the depth range of $200-450 \mathrm{~km}$ is shown in Figure 8, together with the result obtained by using the seismic velocity [4] and the result for a pyrolitic upper mantle [18]. The $(\partial T / \partial z)_{S}$ value of the upper mantle was presented as a constant of $0.3 \mathrm{~K} / \mathrm{km}$ in an early study [5]; later, a higher value was suggested at the top part of the upper mantle $(0.4-0.5 \mathrm{~K} / \mathrm{km})[4,18]$. In Figure 8 , the $(\partial T / \partial z)_{S}$ value of the eclogitic model decreases from $0.39 \mathrm{~K} / \mathrm{km}$ to $0.34 \mathrm{~K} / \mathrm{km}$ at a depth range of $200-410 \mathrm{~km}$ when $T_{P}=1623 \mathrm{~K}$, which is $\sim 12 \%$ lower than that presented by Stacey and Davis [4]. Also, the $(\partial T / \partial z)_{S}$ value of the eclogite model is $\sim 17 \%$ lower than that of the pyrolite model suggested by Katsura et al. [18] at $200 \mathrm{~km}$, but increasing the depth to $410 \mathrm{~km}$, the values become closer, with a difference of $4 \%$. Under $410 \mathrm{~km}$, the $(\partial T / \partial z)_{S}$ value of the eclogite model maintains the same trend as the depth and decreases to $0.33 \mathrm{~K} / \mathrm{km}$ at $450 \mathrm{~km}$, while the $(\partial T / \partial z)_{S}$ value of the pyrolite model shows an increase because of the olivine-wadsleyite transition. Moreover, the value of $(\partial T / \partial z)_{S}$ for the eclogite model shows a $\sim 5 \%$ increase with $T_{P}$ increasing from $1623 \mathrm{~K}$ to $1683 \mathrm{~K}$; the values are $0.41 \mathrm{~K} / \mathrm{km}$, $0.35 \mathrm{~K} / \mathrm{km}$, and $0.34 \mathrm{~K} / \mathrm{km}$ at depths of $200 \mathrm{~km}, 410 \mathrm{~km}$, and $450 \mathrm{~km}$, respectively.

Our obtained adiabatic geotherm of an eclogitic mantle from $200 \mathrm{~km}$ to $450 \mathrm{~km}$ is shown in Figure 9. At depths of $200 \mathrm{~km}, 410 \mathrm{~km}$, and $450 \mathrm{~km}$, the temperatures of the eclogite model are $1699 \mathrm{~K}, 1775 \mathrm{~K}$, and $1789 \mathrm{~K}$ when $T_{P}=1623 \mathrm{~K}$, respectively, and $1762 \mathrm{~K}$, $1841 \mathrm{~K}$, and $1855 \mathrm{~K}$ when $T_{P}=1683 \mathrm{~K}$, respectively. Under the condition of $T_{P}=1683 \mathrm{~K}$, the estimated temperature is generally consistent with the results proposed by Stacey and Davis [4] and Trubitsyn and Trubitsyn [69] in the depth range of $\sim 200-410 \mathrm{~km}$, with the differences being less than $0.8 \%$ and $1 \%$, respectively, but $\sim 80 \mathrm{~K}$ higher than the results obtained by Anderson [8] and Brown and Shankland [9] at a depth of $410 \mathrm{~km}$. By comparing the depth of the $410 \mathrm{~km}$ discontinuity with the forsterite-wadsleyite phase transition pressure, the temperature at a depth of $409 \mathrm{~km}$ was determined to be $1830 \pm 48 \mathrm{~K}$ for the pyrolite model, and consequently, the $T_{P}$ was presented as $1610 \pm 35 \mathrm{~K}$ [18]. Because of the existence of olivine in the pyrolitic mantle, though the $T_{P}$ of the pyrolite model is lower than that of the eclogite model, the higher $(\partial T / \partial z)_{S}$ value of the pyrolite model leads to similar temperatures to the eclogite model in the depth range of $200-410 \mathrm{~km}$. However, the temperature of the eclogite model does not show the increase demonstrated in the pyrolite model at the $410 \mathrm{~km}$ discontinuity, but maintains the same trend at a depth of $450 \mathrm{~km}$. 


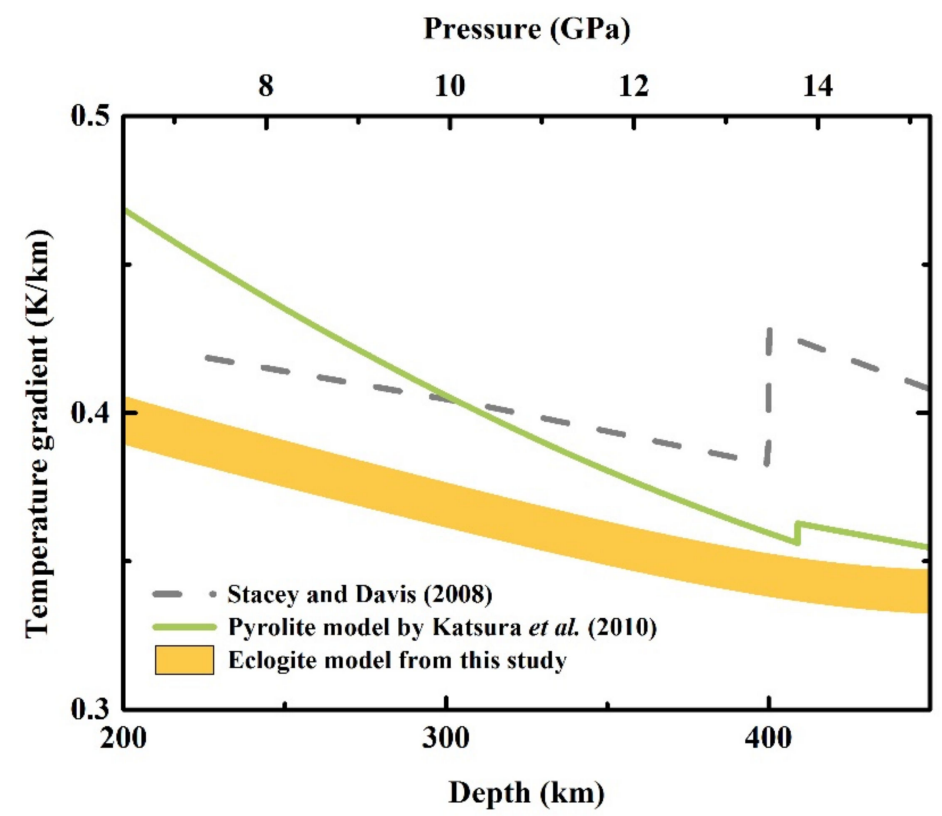

Figure 8. Adiabatic temperature gradients in the depth range of $200-450 \mathrm{~km}$. The lower and upper edges of the filled area are calculated with $T_{P}$ as $1623 \mathrm{~K}$ and $1683 \mathrm{~K}$, respectively.

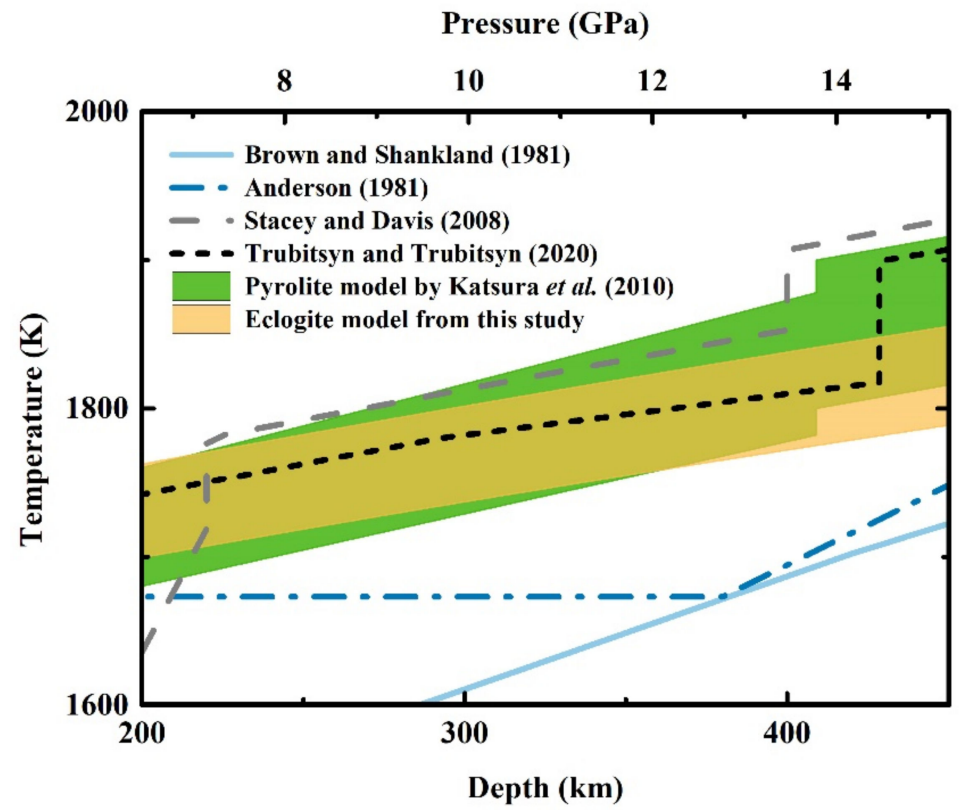

Figure 9. Adiabatic geotherm in the depth range of $200-450 \mathrm{~km}$. The lower and upper edges of the filled area are calculated with $T_{P}$ as $1623 \mathrm{~K}$ and $1683 \mathrm{~K}$, respectively.

It is worth noting that, except for olivine, the peridotitic garnet, clinopyroxene, and orthopyroxene are essential compositions in a pyrolite mantle [67,70]. Additionally, the majority of the clinopyroxene in an eclogite mantle is considered to be omphacite, which is mainly composed of diopside and jadeite $\left(\mathrm{NaAlSi}_{2} \mathrm{O}_{6}\right)$ [71]. Also, the majoritic garnet becomes dominant over a depth of $\sim 450 \mathrm{~km}$ [59-61]. Furthermore, $\mathrm{Fe}$ is a non-negligible content in both olivine and clinopyroxene [72,73]. Previous studies have suggested that Fe incorporation could increase the estimated adiabatic temperature gradient [20]. Hence, the differences between the geotherm of the pyrolite and eclogite models are probably not the same as what we described if we consider more complicated mineral compositions for the pyrolite model. More thermodynamic parameters of mantle minerals are still required to improve the geotherm model. Overall, this study shows that the adiabatic temperature 
gradient and adiabatic geotherm of different mantle compositions exhibit various trends with depth. As a consequence, suitable geotherms need to be taken into account when investigating different tectonic settings.

\section{Conclusions}

In summary, following a numerical iterative procedure, we obtained self-consistent thermodynamic parameters: thermal expansion, heat capacity, and Grüneisen parameters of diopside in a wide $P-T$ range $(20 \mathrm{GPa}, 2000 \mathrm{~K})$. All these thermodynamic parameters are nonlinearly and negatively correlated with pressure. Also, the pressure effects on thermal expansion and heat capacity increase with temperature, while the effect of pressure on the Grüneisen parameter decreases to a minimum at $\sim 500 \mathrm{~K}$, then increases with temperature again. Based on thermodynamic data on major mantle minerals from this and previous studies, we have estimated the adiabatic temperature gradient and geotherm of an eclogitic upper mantle. The results suggest that the adiabatic temperature gradient of the eclogite model is lower than that of the pyrolite model at the same depth, which causes a slower rise of temperature than that of a pyrolitic upper mantle and leads to a similar adiabatic geotherm for both pyrolitic and eclogitic upper mantle in the depth range of $200-410 \mathrm{~km}$.

Supplementary Materials: The following are available online at https: / www.mdpi.com/article/ 10.3390/min11121322/s1, File S1: MS Excel spreadsheet for unit-cell volume of diopside (unit-cell volume.xlsx), File S2: MS Excel spreadsheet for isothermal bulk modulus of diopside (isothermal bulk modulus.xlsx), File S3: MS Excel spreadsheet for adiabatic bulk modulus of diopside (adiabatic bulk modulus.xlsx), File S4: MS Excel spreadsheet for shear modulus of diopside (shear modulus.xlsx), File S5: MS Excel spreadsheet for thermal expansion of diopside (thermal expansion.xlsx), File S6: MS Excel spreadsheet for heat capacity of diopside (heat capacity.xlsx), File S7: MS Excel spreadsheet for Grüneisen parameter of diopside (Grüneisen parameter.xlsx).

Author Contributions: Conceptualization, C.S., Y.L. and D.F.; methodology, C.S., Y.L. and D.F.; software, G.Y.; resources, J.J., Z.S., Y.W. and W.Q.; data curation, C.S.; writing-original draft preparation, C.S.; writing-review and editing, C.S., Y.L., D.F. and W.S.; supervision, Y.L. and D.F.; project administration, Y.L. and D.F.; funding acquisition, C.S. and Y.L. All authors have read and agreed to the published version of the manuscript.

Funding: This research was funded by the Science and Technology Project for the Langfang City [2021013079] and the National Natural Science Foundation of China [41873075].

Data Availability Statement: Data is contained within the article or supplementary material.

Acknowledgments: The authors thank Wenge Zhou at the Institute of Geochemistry, Chinese Academy of Sciences for helpful discussions and suggestions. We also thank Peter I. Dorogokupets at the Institute of the Earth Crust SB RAS and two anonymous reviewers for their insightful comments and suggestions that were very valuable for improving our manuscript.

Conflicts of Interest: The authors declare no conflict of interest.

\section{References}

1. Weidner, D.J.; Wang, Y. Phase transformations: Implications for mantle structure. In Earth's Deep Interior: Mineral. Physics and Tomography From the Atomic to the Global Scale; American Geophysical Union: Washington, DC, USA, 2000; pp. $215-235$.

2. Akaogi, M.; Ito, E.; Navrotsky, A. Olivine-modified spinel-spinel transitions in the system $\mathrm{Mg}_{2} \mathrm{SiO}_{4}-\mathrm{Fe}_{2} \mathrm{SiO}_{4}$ : Calorimetric measurements, thermochemical calculation, and geophysical application. J. Geophys. Res. Solid Earth 1989, 94, 15671-15685. [CrossRef]

3. Ono, S. Experimental constraints on the temperature profile in the lower mantle. Phys. Earth Planet. Inter. 2008, 170, 267-273. [CrossRef]

4. Stacey, F.; Davis, P. Physics of the Earth; Cambridge Univ. Press: Cambridge, UK, 2008.

5. Turcotte, D.L.; Schubert, G. Geodynamics, 2nd ed.; Cambridge University Press: Cambridge, UK, 2012.

6. Dziewonski, A.M.; Hales, A.L.; Lapwood, E.R. Parametrically simple earth models consistent with geophysical data. Phys. Earth Planet. Inter. 1975, 10, 12-48. [CrossRef]

7. Stacey, F.D. A thermal model of the earth. Phys. Earth Planet. Inter. 1977, 15, 341-348. [CrossRef]

8. Anderson, O.L. Temperature profiles in the Earth. Evol. Earth 1981, 5, 19-27. 
9. Brown, J.M.; Shankland, T.J. Thermodynamic parameters in the Earth as determined from seismic profiles. Geophys. J. Int. 1981, 66, 579-596. [CrossRef]

10. Jeanloz, R.; Richter, F.M. Convection, composition, and the thermal state of the lower mantle. J. Geophys. Res. 1979, 84, 5497-5504. [CrossRef]

11. Ringwood, A.E. A model for the upper mantle. J. Geophys. Res. 1962, 67, 4473-4478. [CrossRef]

12. Bass, J.D.; Anderson, D.L. Composition of the upper mantle: Geophysical tests of two petrological models. Geophys. Res. Lett. 1984, 11, 229-232. [CrossRef]

13. Katsura, T. Thermal expansion of $\mathrm{Mg}_{2} \mathrm{SiO}_{4}$ ringwoodite at high pressures. J. Geophys. Res. 2004, 109, 209-218. [CrossRef]

14. Katsura, T.; Shatskiy, A.; Manthilake, M.A.G.M.; Zhai, S.; Fukui, H.; Yamazaki, D.; Matsuzaki, T.; Yoneda, A.; Ito, E.; Kuwata, A.; et al. Thermal expansion of forsterite at high pressures determined by in situ X-ray diffraction: The adiabatic geotherm in the upper mantle. Phys. Earth Planet. Inter. 2009, 174, 86-92. [CrossRef]

15. Katsura, T.; Shatskiy, A.; Manthilake, M.A.G.M.; Zhai, S.; Yamazaki, D.; Matsuzaki, T.; Yoshino, T.; Yoneda, A.; Ito, E.; Sugita, M.; et al. P-V-T relations of wadsleyite determined by in situ X-ray diffraction in a large-volume high-pressure apparatus. Geophys. Res. Lett. 2009, 36, 1-5.

16. Katsura, T.; Yamada, H.; Nishikawa, O.; Song, M.; Kubo, A.; Shinmei, T.; Yokoshi, S.; Aizawa, Y.; Yoshino, T.; Walter, M.J.; et al. Olivine-wadsleyite transition in the system $(\mathrm{Mg}, \mathrm{Fe})_{2} \mathrm{SiO}_{4}$. J. Geophys. Res. Solid Earth 2004, 109, 1-12. [CrossRef]

17. Katsura, T.; Yokoshi, S.; Kawabe, K.; Shatskiy, A.; Manthilake, M.A.G.M.; Zhai, S.; Fukui, H.; Hegoda, H.A.C.I.; Yoshino, T.; Yamazaki, D.; et al. P-V-T relations of $\mathrm{MgSiO}_{3}$ perovskite determined by in situ X-ray diffraction using a large-volume high-pressure apparatus. Geophys. Res. Lett. 2009, 36, 1-6.

18. Katsura, T.; Yoneda, A.; Yamazaki, D.; Yoshino, T.; Ito, E. Adiabatic temperature profile in the mantle. Phys. Earth Planet. Inter. 2010, 183, 212-218. [CrossRef]

19. Su, C.; Liu, Y. Thermal expansion, heat capacity and Grüneisen parameter of grossular at high temperature and high pressure. High. Temp.-High. Press. 2021, 50, 105-119.

20. Su, C.; Liu, Y.; Fan, D.; Song, W.; Yang, G. Self-consistent thermodynamic parameters of pyrope and almandine at high-temperature and high-pressure conditions: Implication on the adiabatic temperature gradient. Phys. Earth Planet. Inter. 2021, 106789. [CrossRef]

21. Su, C.; Liu, Y.; Song, W.; Fan, D.; Wang, Z.; Tang, H. Thermodynamic properties of San Carlos olivine at high temperature and high pressure. Acta Geochim. 2018, 37, 171-179. [CrossRef]

22. Ringwood, A.E. Phase transformations and the constitution of the mantle. Phys. Earth Planet. Inter. 1970, 3, 109-155. [CrossRef]

23. Li, B.; Neuville, D.R. Elasticity of diopside to $8 \mathrm{GPa}$ and $1073 \mathrm{~K}$ and implications for the upper mantle. Phys. Earth Planet. Inter. 2010, 183, 398-403. [CrossRef]

24. Zou, F.; Wu, Z.; Wang, W.; Wentzcovitch, R.M. An extended semianalytical approach for thermoelasticity of monoclinic crystals: Application to diopside. J. Geophys. Res. Solid Earth 2018, 123, 7629-7643. [CrossRef]

25. Zhao, Y.; Dreele, R.B.V.; Zhang, J.Z.; Weidner, D.J. Thermoelastic Equation of State of Monoclinic Pyroxene: $\mathrm{CaMgSi}_{2} \mathrm{O}_{6} \mathrm{Diopside}$ Rev. High. Press. Sci. Technol. 1998, 7, 25-27. [CrossRef]

26. Birch, F. Finite Elastic Strain of Cubic Crystals. Phys. Rev. 1947, 71, 809-824. [CrossRef]

27. Jackson, I.; Rigden, S.M. Analysis of P-V-T data: Constraints on the thermoelastic properties of high-pressure minerals. Phys. Earth Planet. Inter. 1996, 96, 85-112. [CrossRef]

28. Pandolfo, F.; Cámara, F.; Domeneghetti, M.C.; Alvaro, M.; Nestola, F.; Karato, S.-I.; Amulele, G. Volume thermal expansion along the jadeite-diopside join. Phys. Chem. Miner. 2015, 42, 1-14. [CrossRef]

29. Hovis, G.L.; Tribaudino, M.; Leaman, A.; Almer, C.; Altomare, C.; Morris, M.; Maksymiw, N.; Morris, D.; Jackson, K.; Scott, B.; et al. Thermal expansion of minerals in the pyroxene system and examination of various thermal expansion models. Am. Mineral. 2021, 106, 883-899. [CrossRef]

30. Krupka, K.M.; Hemingway, B.S.; Robie, R.A.; Kerrick, D.M. High-temperature heat capacities and derived thermodynamic properties of anthophyllite, diopside, dolomite, enstatite, bronzite, talc, tremolite and wollastonite. Am. Mineral. 1985, 70, 261-271.

31. Richet, P.; Fiquet, G. High-temperature heat capacity and premelting of minerals in the system $\mathrm{MgO}-\mathrm{CaO}-\mathrm{Al}_{2} \mathrm{O}_{3}-\mathrm{SiO}{ }_{2}$. J. Geophys. Res. 1991, 96, 445-456. [CrossRef]

32. Stebbins, J.F.; Carmichael, I.S.E.; Weill, D.E. The high temperature liquid and glass heat contents and the heats of fusion of diopside, albite, sanidine and nepheline. Am. Mineral. 1983, 68, 717-730.

33. Isaak, D.G.; Ohno, I.; Lee, P.C. The elastic constants of monoclinic single-crystal chrome-diopside to 1300 K. Phys. Chem. Miner. 2006, 32, 691-699. [CrossRef]

34. De Koker, N.; Stixrude, L. Self-consistent thermodynamic description of silicate liquids, with application to shock melting of $\mathrm{MgO}$ periclase and $\mathrm{MgSiO}_{3}$ perovskite. Geophys. J. Int. 2009, 178, 162-179. [CrossRef]

35. Sokolova, T.S.; Dorogokupets, P.I. Equations of State of Ca-Silicates and Phase Diagram of the $\mathrm{CaSiO}_{3} \mathrm{System}_{\mathrm{s} d e r} \mathrm{Upper}$ Mantle Conditions. Minerals 2021, 11, 322. [CrossRef]

36. Angel, R.J. Equations of State. Rev. Mineral. Geochem. 2000, 41, 35-59. [CrossRef]

37. Sang, L.; Bass, J.D. Single-crystal elasticity of diopside to 14 GPa by Brillouin scattering. Phys. Earth Planet. Inter. 2014, 228, 75-79. [CrossRef] 
38. Cameron, M.; Sueno, S.; Prewitt, C.T.; Papike, J.J. High-Temperature Crystal Chemistry of Acmite, Diopside, Hedenbergite Jadeite, Spodumene and Ureyite. Am. Mineral. 1973, 58, 594-618.

39. Finger, L.W.; Ohashi, Y. The thermal expansion of diopside to $800{ }^{\circ} \mathrm{C}$ and a refinement of the crystal structure at $700{ }^{\circ} \mathrm{C}$. $\mathrm{Am}$. Mineral. 1976, 61, 303-310.

40. Gonzalez-Platas, J.; Alvaro, M.; Nestola, F.; Angel, R. EosFit7-GUI: A new graphical user interface for equation of state calculations, analyses and teaching. J. Appl. Crystallogr. 2016, 49, 1377-1382. [CrossRef]

41. Fei, Y. Thermal Expansion. In Mineral. Physics \& Crystallography; Ahrens, T.J., Ed.; American Geophysical Union: Washington, DC, USA, 1995; pp. 29-44.

42. Thompson, R.M.; Downs, R.T. The crystal structure of diopside at pressure to 10 GPa. Am. Mineral. 2008, 93, 177-186. [CrossRef]

43. Tribaudino, M.; Prencipe, M.; Bruno, M.; Levy, D. High-pressure behaviour of Ca-rich C2/c clinopyroxenes along the join diopside-enstatite $\left(\mathrm{CaMgSi}_{2} \mathrm{O}_{6}-\mathrm{Mg}_{2} \mathrm{Si}_{2} \mathrm{O}_{6}\right)$. Phys. Chem. Miner. 2000, 27, 656-664. [CrossRef]

44. Levien, L.; Prewitt, C.T. High-pressure structural study of diopside. Am. Mineral. 1981, 66, 315-323.

45. Sang, L.; Vanpeteghem, C.B.; Sinogeikin, S.V.; Bass, J.D. The elastic properties of diopside, CaMgSi $2 \mathrm{O}_{6}$. Am. Mineral. 2011, 96, 224-227. [CrossRef]

46. Walker, A.M.; Tyer, R.P.; Bruin, R.P.; Dove, M.T. The compressibility and high pressure structure of diopside from first principles simulation. Phys. Chem. Miner. 2008, 35, 359-366. [CrossRef]

47. Saxena, S.K.; Chatterjee, N.; Fei, Y.; Shen, G. Thermodynamic Data on Oxides and Silicates. An Assessed Data Set Based on Thermochemistry and High Pressure Phase Equilibrium, 1st ed.; Springer: Berlin/Heidelberg, Germany, 1993.

48. Vočadlo, N.L.; Price, G.D. The Grüneisen parameter-computer calculations via lattice dynamics. Phys. Earth Planet. Inter. 1994, 82, 261-270. [CrossRef]

49. Wu, Z.; Wentzcovitch, R.M. Vibrational and thermodynamic properties of wadsleyite: A density functional study. J. Geophys. Res. 2007, 112. [CrossRef]

50. McKenzie, D.; Bickle, M.J. The volume and composition of melt generated by extension of the lithosphere. J. Petrol. 1988, 29, 625-679. [CrossRef]

51. Ringwood, A.E. Phase transformations and their bearing on the constitution and dynamics of the mantle. Geochim. Et Cosmochim. Acta 1991, 55, 2083-2110. [CrossRef]

52. Ringwood, A.E. Phase transformations in the mantle. Earth Planet. Sci. Lett. 1968, 5, 401-412. [CrossRef]

53. Muir, J.M.R.; Zhang, F.; Brodholt, J.P. The effect of water on the post-spinel transition and evidence for extreme water contents at the bottom of the transition zone. Earth Planet. Sci. Lett. 2021, 565, 116909. [CrossRef]

54. Ringwood, A.E. Phase Transformations and Differentiation in Subducted Lithosphere: Implications for Mantle Dynamics, Basalt Petrogenesis, and Crustal Evolution. J. Geol. 1982, 90, 611-643. [CrossRef]

55. Ringwood, A.E.; Irifune, T. Nature of the 650-km seismic discontinuity: Implications for mantle dynamics and differentiation. Nature 1988, 331, 131-136. [CrossRef]

56. Ishii, T.; Kojitani, H.; Akaogi, M. Phase Relations of Harzburgite and MORB up to the Uppermost Lower Mantle Conditions: Precise Comparison with Pyrolite by Multisample Cell High-Pressure Experiments with Implication to Dynamics of Subducted Slabs. J. Geophys. Res. Solid Earth 2019, 124, 3491-3507. [CrossRef]

57. Green, D.H.; Ringwood, A.E. An experimental investigation of the gabbro to eclogite transformation and its petrological applications. Geochim. Et Cosmochim. Acta 1967, 31, 767-833. [CrossRef]

58. Poli, S. The amphibolite-eclogite transformation; an experimental study on basalt. Am. J. Sci. 1993, 293, 1061-1107. [CrossRef]

59. Akaogi, M.; Akimoto, S. Pyroxene-garnet solid-solution equilibria in the systems $\mathrm{Mg}_{4} \mathrm{Si}_{4} \mathrm{O}_{12}-\mathrm{Mg}_{3} \mathrm{Al}_{2} \mathrm{Si}_{3} \mathrm{O}_{12}$ and $\mathrm{Fe}_{4} \mathrm{Si}_{4} \mathrm{O}_{12}-$ $\mathrm{Fe}_{3} \mathrm{Al}_{2} \mathrm{Si}_{3} \mathrm{O}_{12}$ at high pressures and temperatures. Phys. Earth Planet. Inter. 1977, 15, 90-106. [CrossRef]

60. Irifune, T. Phase transformations in the earth's mantle and subducting slabs: Implications for their compositions, seismic velocity and density structures and dynamics. Isl. Arc. 1993, 2, 55-71. [CrossRef]

61. Kiseeva, E.S.; Yaxley, G.M.; Stepanov, A.S.; Tkalčić, H.; Litasov, K.D.; Kamenetsky, V.S. Metapyroxenite in the mantle transition zone revealed from majorite inclusions in diamonds. Geology 2013, 41, 883-886. [CrossRef]

62. Presnall, D.C.; Gudfinnsson, G.H.; Walter, M.J. Generation of mid-ocean ridge basalts at pressures from 1 to 7 GPa. Geochim. Et Cosmochim. Acta 2002, 66, 2073-2090. [CrossRef]

63. Putirka, K.D. Mantle potential temperatures at Hawaii, Iceland, and the mid-ocean ridge system, as inferred from olivine phenocrysts: Evidence for thermally driven mantle plumes. Geochem. Geophys. Geosystems 2005, 6, 1-14. [CrossRef]

64. Dalton, C.A.; Langmuir, C.H.; Gale, A. Geophysical and geochemical evidence for deep temperature variations beneath mid-ocean ridges. Science 2014, 344, 80-83. [CrossRef] [PubMed]

65. Sarafian, E.; Gaetani, G.A.; Hauri, E.H.; Sarafian, A.R. Experimental constraints on the damp peridotite solidus and oceanic mantle potential temperature. Science 2017, 355, 942-945. [CrossRef] [PubMed]

66. Irifune, T.; Sekine, T.; Ringwood, A.E.; Hibberson, W.O. The eclogite-garnetite transformation at high pressure and some geophysical implications. Earth Planet. Sci. Lett. 1986, 77, 245-256. [CrossRef]

67. Duan, L.; Wang, W.; Wu, Z.; Qian, W. Thermodynamic and Elastic Properties of Grossular at High Pressures and High Temperatures: A First-Principles Study. J. Geophys. Res. Solid Earth 2019, 124, 7792-7805. [CrossRef] 
68. Xu, J.; Zhang, D.; Fan, D.; Dera, P.K.; Shi, F.; Zhou, W. Thermoelastic Properties of Eclogitic Garnets and Omphacites: Implications for Deep Subduction of Oceanic Crust and Density Anomalies in the Upper Mantle. Geophys. Res. Lett. 2019, 46, 179-188. [CrossRef]

69. Trubitsyn, A.P.; Trubitsyn, V.P. Temperature Distribution in the Earth's Mantle. Dokl. Earth Sci. 2020, 495, 905-909. [CrossRef]

70. Green, D.H.; Ringwood, A.E. Mineralogy of peridotitic compositions under upper mantle conditions. Phys. Earth Planet. Inter. 1970, 3, 359-371. [CrossRef]

71. Liu, L.-G. The mineralogy of an eclogitic earth mantle. Phys. Earth Planet. Inter. 1980, 23, 262-267. [CrossRef]

72. Ringwood, A.E.; Major, A. The system $\mathrm{Mg}_{2} \mathrm{SiO}_{4}-\mathrm{Fe}_{2} \mathrm{SiO}_{4}$ at high pressures and temperatures. Phys. Earth Planet. Inter. 1970, 3 , 89-108. [CrossRef]

73. Canil, D.; O’Neill, H.S.C. Distribution of Ferric Iron in some Upper-Mantle Assemblages. J. Petrol. 1996, 37, 609-635. [CrossRef] 